No. 2: Official Opening of the Institute, 17th March, 1979Speeches by Professor B. Kwaku Adadevoh and Dr. Taslim O. Elias (15 pp.).

No. 3: Commonwealth Legal Co-Operation, by Professor Sir Roy Marshall (16 pp.).

No. 4: A Bibliography of the Workings of the Hon. Judge T.O. Elias, by Oluremi Jegede (54 pp.).

All publications are available from the Nigerian Institute of Advanced Legal Studies in Lagos, Nigeria.

\title{
LEGAL DOCUMENTATION CENTERS IN THE NETHERLANDS
}

T.M.C. Asser Instituut,

Alexander 22, 's-Gravenhage.

Specializes in international law, European Communities law, and private international law.

Documentatiebureau voor Oost-Europeesrecht,

Hugo de Grootstratt 32, Leiden.

East European law.

Nederlands Centrum voor Rechtshistorische Documentatie,

Oude Zijds Achterburgwal 217-219, Amsterdam.

Legal history.

Internationaal Bureau Voor Belasting Documentatie,

Sarphatistratt 124, Amsterdam.

Taxation.

(Information is based on a list published in the October 1979 issue of De Juridische Bibliothecaris, Information Bulletin of the Dutch Association of Law Libraries and Legal Documentations Centers.) 